\title{
PEMBERIAN SUSU KEDELAI TERHADAP PENURUNAN TEKANAN DARAH PADA PENDERITA HIPERTENSI DI DESA PRINGKUMPUL PRINGSEWU SELATAN
}

\author{
GIVING SOYBEAN MILK TO REDUCE BLOOD PRESSURE IN \\ HYPERTENSION PATIENTS IN PRINGSEWU SELATAN PRINGKUMPUL \\ VILLAGE
}

\author{
Andri Yulianto ${ }^{1}$ Tristiningsih $^{2}$ Nur Fadhilah $^{3}$ \\ ${ }^{123}$ Fakultas Kesehatan Universitas Muhammadiyah Pringsewu \\ Email : andrri.yuliianto@gmail.com
}

\begin{abstract}
AbsIrak: Giving Soybean Milk To Reduce Blood Pressure In Hypertension Patients In Pringsewu Selatan Pringkumpul Village. Hypertension is a condition in which a person's blood pressure above normal which is more than $140 / 90 \mathrm{mmHg}$. Hypertension require both pharmacological therapy and nonpharmacological or complementary therapies. One of them is the consumption of soy milk. The purpose of this study was to determine the influence of the effectiveness of soy milk to the reduction of blood pressure in hypertensive patients in South Pringsewu Pringkumpul village in 2015.This study uses a quasi true experiment design with one group pretest posttest model of the 27 respondents with hypertension who meet the inclusion and exclusion criteria. The method used is purposive sampling. Data collected by the observation sheet and tensimeter mercury. Results Paired sample t-test there is a significant effect on systolic and diastolic blood pressure in hypertensive patients before and after treatment with $\mathrm{p}=0.000$ (systolic) and $\mathrm{p}=0.000$ (diastolic) where $\mathrm{p}<0.05$. This indicates that administration of soy milk can lower blood pressure in hypertensive patients. Expected for the community and the medical world can use soy milk as a complementary therapy to treat hypertension.

Key words: Soymilk, Blood Pressure, Hypertension
\end{abstract}

\begin{abstract}
Abstrak: Pemberian Susu Kedelai Terhadap Penurunan Tekanan Darah Pada Penderita Hipertensi Di Desa Pringkumpul Pringsewu Selatan. Hipertensi adalah dimana sesorang mengalami tekanan darah diatas $140 / 90 \mathrm{mmHg}$. Hipertensi memerlukan penanganan atau terapi baik secara farmakologi maupun nonfarmakologi (komplementer). Salah satunya yaitu dengan konsumsi susu kedelai. Tujuan penelitian ini adalah mengetahui pengaruh konsumsi susu kedelai terhadap penurunan tekanan darah pada pasien hipertensi di Desa Pringkumpul Pringsewu Selatan pada tahun 2015. Penelitian ini menggunakan desain True Experimen dengan model one group pretest posttest pada 27 responden hipertensi. Metode yang digunakan adalah total population. Pengumpulan data dilakukan dengan lembar observasi dan tensimeter air raksa. Hasil uji Paired sample T-test terdapat pengaruh yang bermakna pada tekanan darah sistolik dan diastolik pasien hipertensi sebelum dan sesudah terapi dengan nilai $\mathrm{p}=0,000$ (sistolik) dan $\mathrm{p}=0,000$ (diastolik) dimana $\mathrm{p}<0,05$. Hal ini menunjukkan bahwa mengkonsumsi susu kedelai dapat menurunkan tekanan darah pada pasien hipertensi. Diharapkan bagi masyarakat dan dunia medis dapat menggunakan susu kedelai sebagai salah satu terapi komplementer dalam mengatasi hipertensi.

Kata kunci : susu kedelai, tekanan darah, hipertensi
\end{abstract}

\section{PENDAHULUAN}

Hipertensi merupakan resiko morbiditas dan mortalitas, yang meningkat sesuai dengan peningkatan tekanan sistolik dan diastolik. Jumlah penderita hipertensi diseluruh dunia mencapai 972 juta jiwa, sebanyak 330 juta diantaranya berada dinegara maju (Eropa, Amerika, dan Jepang), sisanya kurang dari 600 juta berada di Negara yang sedang berkembang termasuk Indonesia (Dicky, 2011). 
Vol 10 No 1 Januari 2021 | Page 54-63

Hipertensi menjadi masalah kesehatan di seluruh dunia karena prevalensinya yang tinggi. Tahun 2011 ada satu milyar orang didunia menderita hipertensi dan 2/3 diantaranya berada di Negara berkembang yang penghasilan rendah-sedang. Prevalensi hipertensi diperkirakan akan terus meningkat dan diprediksi pada tahun 2025 sebanyak $29 \%$ orang dewasa diseluruh dunia menderita hipertensi (Rahajeng \& Tuminah, 2015).

Data di Amerika diperkirakan 25\% penduduk usia dewasa menderita hipertensi. Apabila penyakit ini tidak terkontrol dapat menyebabkan peluang 7 kali lebih besar terkena stroke, 6 kali lebih besar terkena congestive heart failure, dan 3 kali lebih besar terkena serangan jantung. Menurut WHO dan the International Society of Hypertension (ISH), saat ini terdapat 600 juta penderita hipertensi di seluruh dunia, dan 3 juta diantaranya meninggal setiap tahunya. Tujuh dari setiap 10 penderita tersebut tidak mendapatkan pengobatan secara adekuat (Dicky, 2010).

Data Riset Kesehatan Dasar (Riskesdas) di Indonesia, menunjukkan sebagian besar kasus hipertensi di masyarakat belum terdiagnosis. Hasil pengukuran tekanan darah pada usia 18 tahun ke atas ditemukan prevalensi hipertensi di Indonesia sebesar 31,7\%. Data Riskesdas tahun 2013 mencatat prevalensi hipertensi pada tahun 2013 yaitu 25,8\%. Meskipun mengalami penurunan, prevalensi ini jauh lebih tinggi dibandingkan dengan Thailand (22,7\%) dan Malaysia (20\%).

Kejadian hipertensi di Lampung mencapai $24,7 \%$. Hasil tersebut lebih tinggi dari provinsi yang terdekat seperti jambi yang hanya 24,6\%, Bengkulu 21,6\% (Riskesdas, 2013). Berdasarkan catatan dines kesehatan pringsewu, jumlah hipertensi pada tahun 2013 mencapai 5,7\% dan pada tahun 2014 mencapai 8,69\%, dan di puskesmas pringsewu paling tinggi dari 11 puskesmas di Kabupaten Pringsewu yaitu mencapai 12,97\% pada tahun 2014 (Dinkes Pringsewu, 2014).

\section{METODE}

Metode yang digunakan pada penelitian ini adalah True Exsperimen yang bertujuan untuk mengetahui efektifitas pemberian susu kedelai terhadap penurunan tekanan darah pada penderita hipertensi. Jenis pendekatan yang digunakan ialah pendekatan One Group Pretest-posttest yaitu penelitian yang membandingkan nilai hasil penelitian sebelum dan sesudah diberikanya perlakuan. Aanalisa data yang digunakan dengan uji statistik T-test (Wilcoxon) dengan tingkat kepercayaan 95\% atau dapat pula dengan perbandingan nilai p-value dengan nilai $\alpha=0.05$.

\section{HASIL}

\section{Hasil Analisa Univariat}

Analisa ini bertujuan untuk mendeskripsikan karakteristik setiap variabel penelitian baik variabel independen maupun dependen. Adapun variabel yang dianalisis dalam penelitian ini mencakup usia, jenis kelamin, riwayat merokok dan riwayat hipertensi serta gambaran tentang tekanan darah sebelum dan sesudah pemberian susu kedelai. 
Vol 10 No 1 Januari 2021 | Page 54-63

a. Karakteristik Responden

1) Berdasarkan Usia

Tabel 4.1 Distribusi Frekuensi Responden Berdasarkan Usia di Desa Pringkumpul Pringsewu Selatan

\begin{tabular}{cccc}
\hline No. & Usia & Frekuensi & $\begin{array}{c}\text { Presentase } \\
(\mathbf{\%})\end{array}$ \\
\hline 1 & 26-35 tahun (Dewasa awal) & 1 & 3,7 \\
2 & 36-45 tahun (Dewasa akhir) & 3 & 11,1 \\
3 & 46-55 tahun (Lansia awal) & 9 & 33,3 \\
4 & 56-65 tahun (Lansia akhir) & 10 & 37,0 \\
5 & >65 tahun (Manula) & 4 & 14,8 \\
Jumlah & & $\mathbf{2 7}$ & $\mathbf{1 0 0}$ \\
\hline
\end{tabular}

Berdasarkan tabel 4.1 didapatkan informasi bahwa sebagian besar responden berusia 5665 tahun yaitu 10 orang $(37,0 \% \%)$ dan kelompok usia 46-55 tahun 9 orang $(33,3 \%)$. Dan hanya 1 responden $(3,7 \% \%)$ untuk usia $26-35$ tahun.

2) Berdasarkan Jenis Kelamin

Tabel 4.2 Distribusi Frekuensi Responden Berdasarkan Jenis Kelamin di Desa Pringkumpul Pringsewu Selatan

\begin{tabular}{cccc}
\hline No. & $\begin{array}{c}\text { Jenis } \\
\text { Kelamin }\end{array}$ & Frekuensi & Presentase (\%) \\
& Laki-Laki & 14 & 51,9 \\
2 & Perempuan & 13 & 48,1 \\
& Jumlah & $\mathbf{2 7}$ & $\mathbf{1 0 0}$ \\
\hline
\end{tabular}

Berdasarkan tabel 4.2 didapatkan informasi bahwa jenis kelamin laki-laki lebih banyak dibandingkan perempuan, yaitu 14 responden $(51,9 \%)$ sedangkan yang berjenis kelamin perempuan sebanyak 13 responden yaitu $(48,1 \%)$.

3) Berdasarkan Pendidikan

Tabel 4.3 Distribusi Responden Berdasarkan Pendidikan di Desa Pringkumpul Pringsewu Selatan

\begin{tabular}{cccc}
\hline No. & Pendidikan & Frekuensi & Presentase (\%) \\
\hline 1 & SD & 16 & 59,3 \\
$\mathbf{2}$ & SMP & 5 & 18,5 \\
$\mathbf{3}$ & SMA & 4 & 14,8 \\
4 & SARJANA & 2 & 7,4 \\
& Jumlah & $\mathbf{2 7}$ & $\mathbf{1 0 0}$ \\
\hline
\end{tabular}

Berdasarkan tabel 4.3 didapatkan informasi bahwa tingkat pendidikan responden sebagian besar SD yaitu 16 responden $(59,3 \%)$ dan responden dengan pendidikan Sarjana hanya 2 orang $(7,4 \%)$. 
Vol 10 No 1 Januari 2021 | Page 54-63

4) Berdasarkan Pekerjaan

Tabel 4.4 Distribusi Frekuensi Responden Berdasarkan Pekerjaan Di Desa Pringkumpul Pringsewu Selatan

\begin{tabular}{clcc}
\hline No. & Pekerjaan & Frekuensi & Presentase (\%) \\
\hline 1 & Tidak & 6 & 22,2 \\
& bekerja & 7 & 25,9 \\
2 & Petani & 12 & 44,4 \\
3 & Wiraswasta & 2 & 7,4 \\
4 & PNS & $\mathbf{2 7}$ & $\mathbf{1 0 0}$ \\
\hline
\end{tabular}

Berdasarkan tabel 4.4 didapatkan informasi bahwa sebagian besar pekerjaan responden adalah wiraswasta yaitu 12 responden $(44,4 \%)$. Dan hanya 2 responden $(7,4 \%)$ dengan status pekerjaan PNS.

b. Berdasarkan Riwayat Hipertensi

Tabel 4.5 Distribusi Frekuensi Responden Berdasarkan Riwayat Hipertensi Desa Pringkumpul Pringsewu Selatan

\begin{tabular}{clcc}
\hline No. & Riwayat Hipertensi & Frekuensi & Presentase (\%) \\
\hline 1 & Hipertensi & 18 & 66,7 \\
2 & Tidak hipertensi & 9 & 33,3 \\
& Jumlah & $\mathbf{2 7}$ & $\mathbf{1 0 0}$ \\
\hline
\end{tabular}

Berdasarkan Tabel 4.5 didapatkan informasi bahwa lebih banyak responden dengan riwayat hipertensi, yaitu 18 responden $(66,7 \%)$ dibandingkan dengan yang tidak memiliki riwayat hipertensi yaitu hanya 9 responden $(33,3 \%)$.

c. Berdasarkan Riwayat Merokok

Tabel 4.6 Distribusi Frekuensi Responden Berdasarkan Riwayat Merokok di Desa Pringkumpul Pringsewu Selatan

\begin{tabular}{clcc}
\hline No. & Riwayat Merokok & Frekuensi & Presentase (\%) \\
\hline 1 & Merokok & 15 & 55,6 \\
2 & Tidakmerokok & 12 & 44,4 \\
& Jumlah & $\mathbf{2 7}$ & $\mathbf{1 0 0}$ \\
\hline
\end{tabular}

Berdasarkan Tabel 4.6 didapatkan informasi bahwa sebagian besar yaitu 15 responden $(55,6 \%)$ dengan riwayat merokok. 
Vol 10 No 1 Januari 2021 | Page 54-63

d. Tekanan Darah Sistolik Sebelum Pemberian Susu Kedelai

Tabel 4.7 Distribusi Frekuensi Responden Berdasarkan Tekanan Darah Sistolik Sebelum Pemberian Susu Kedelai Pada Pasien Hipertensi di Desa Pringkumpul Pringsewu Selatan

\begin{tabular}{cccc}
\hline No. & $\begin{array}{c}\text { Tekanan Darah Sistolik } \\
\text { Sebelum Pemberian Susu } \\
\text { Kedelai }\end{array}$ & Frekuensi & Presentase (\%) \\
\hline 1 & $140 \mathrm{mmHg}$ & 11 & 40,7 \\
2 & $150 \mathrm{mmHg}$ & 10 & 37,0 \\
3 & $160 \mathrm{mmHg}$ & 4 & 14,8 \\
4 & $170 \mathrm{mmHg}$ & 1 & 3,7 \\
5 & $180 \mathrm{mmHg}$ & 1 & 3,7 \\
& Jumlah & $\mathbf{2 7}$ & $\mathbf{1 0 0}$ \\
\hline
\end{tabular}

Berdasarkan Tabel 4.7 didapatkan informasi bahwa hasil pengukuran tekanan darah sistolik sebelum dilakukan pemberian susu kedelai 11 dari 27 responden dengan tekanan darah sistolik yaitu $140 \mathrm{mmHg}(47,7 \%)$ dan hanya masing-masing satu responden dengan tekanan darah sistolik 170 dan $180 \mathrm{mmHg}$.

e. Tekanan Darah Diastolik Sebelum Pemberian Susu Kedelai

Tabel 4.8 Distribusi Frekuensi Responden Berdasarkan Tekanan Darah Diastolik Sebelum Pemberian Susu Kedelai Pada Pasien Hipertensi di Desa Pringkumpul Pringsewu Selatan

\begin{tabular}{cccc}
\hline No. & $\begin{array}{c}\text { Tekanan Darah Diastolik Sebelum } \\
\text { Pemberian Susu Kedelai }\end{array}$ & Frekuensi & Presentase (\%) \\
\hline 1 & $80 \mathrm{mmHg}$ & 1 & 3,7 \\
2 & $90 \mathrm{mmHg}$ & 7 & 25,8 \\
3 & $100 \mathrm{mmHg}$ & 8 & 29,6 \\
4 & $110 \mathrm{mmHg}$ & 11 & 40,7 \\
& Jumlah & $\mathbf{2 7}$ & $\mathbf{1 0 0}$ \\
\hline
\end{tabular}

Berdasarkan Tabel 4.8 didapatkan informasi bahwa hasil pengukuran tekanan darah diastolik sebelum dilakukan pemberian susu kedelai dari 27 responden sebagian besar dengan tekanan darah diastolik yaitu $110 \mathrm{mmHg}(40,7 \%)$ dan hanya 1 responden dengan tekanan darah diastolik $80 \mathrm{mmHg}(3,7 \%)$.

f. Tekanan Darah Sistolik Sesudah Pemberian Susu Kedelai

Tabel 4.9 Distribusi Frekuensi Responden Berdasarkan Tekanan Darah Sistolik Sesudah Pemberian Susu Kedelai Pada Pasien Hipertensi di Desa Pringkumpul Pringsewu Selatan

\begin{tabular}{cccc}
\hline No. & $\begin{array}{c}\text { Tekanan Darah Sistolik Sesudah } \\
\text { Pemberian Susu Kedelai }\end{array}$ & Frekuensi & $\begin{array}{c}\text { Presentase } \\
(\boldsymbol{\%})\end{array}$ \\
\hline 1 & $120 \mathrm{mmHg}$ & 5 & 18,5 \\
2 & $130 \mathrm{mmHg}$ & 2 & 7,4 \\
3 & $140 \mathrm{mmHg}$ & 12 & 44,4 \\
\hline
\end{tabular}


Vol 10 No 1 Januari 2021 | Page 54-63

\begin{tabular}{lccc}
\hline 4 & $150 \mathrm{mmHg}$ & 6 & 22,2 \\
5 & $160 \mathrm{mmHg}$ & 2 & 7,4 \\
& Jumlah & $\mathbf{2 7}$ & $\mathbf{1 0 0}$ \\
\hline
\end{tabular}

Berdasarkan Tabel 4.9 didapatkan informasi hasil pengukuran tekanan darah sistolik sesudah dilakukan pemberian susu kedelai dari 27 responden, 12 orang responden $(44,4 \%)$ dengan tekanan darah sistolik sebesar $140 \mathrm{mmHg}$. Dan masing-masing 2 responden dengan tekanan darah $130 \mathrm{mmHg}$ dan $160 \mathrm{mmHg}$.

g. Tekanan Darah Diastolik Sesudah Pemberian Susu Kedelai

Tabel 4.10 Distribusi Frekuensi Responden Berdasarkan Tekanan Darah Sistolik Sesudah Pemberian Susu Kedelai Pada Pasien Hipertensi di Desa Pringkumpul Pringsewu Selatan

\begin{tabular}{cccc}
\hline No. & $\begin{array}{c}\text { Tekanan Darah Diastolik Sesudah } \\
\text { Pemberian Susu Kedelai }\end{array}$ & Frekuensi & Presentase (\%) \\
\hline 1 & $80 \mathrm{mmHg}$ & 7 & 25,9 \\
2 & $90 \mathrm{mmHg}$ & 14 & 51,9 \\
3 & $100 \mathrm{mmHg}$ & 3 & 11,1 \\
4 & $110 \mathrm{mmHg}$ & 3 & 11,1 \\
& Jumlah & $\mathbf{2 7}$ & $\mathbf{1 0 0}$ \\
\hline
\end{tabular}

Berdasarkan Tabel 4.10 didapatkan informasi hasil pengukuran tekanan darah diastolik sesudah dilakukan pemberian susu kedelai dari 27 responden, 51,9\% dengan tekanan darah diastolik $90 \mathrm{mmHg}$ dan masing-masing 3 responden dengan tekanan darah diastolik $100 \mathrm{mmHg}$ dan $110 \mathrm{mmHg}$.

h. Rata-rata Tekanan Darah Sistolik Responden Sebelum dan Sesudah Pemberian Susu Kedelai

Tabel 4.11 Perbedaan Rata-rata Tekanan Darah Sistolik Responden Sebelum dan Sesudah Pemberian susu kedelaiPada Penderita Hipertensi di Desa Pringkumpul Pringsewu Selatan

\begin{tabular}{cccccc}
\hline Tekanan Darah & Jumlah & Rata-rata & Std. Deviasi & Min & Max \\
\hline $\begin{array}{c}\text { Sistolik sebelum } \\
\text { Pemberian Susu Kedelai }\end{array}$ & 27 & 149,26 & 10,350 & 140 & 180 \\
$\begin{array}{c}\text { Sistolik sesudah } \\
\text { Pemberian Susu Kedelai }\end{array}$ & & & & & \\
& 27 & 139,26 & 11,743 & 120 & 160 \\
\hline
\end{tabular}

Berdasarkan hasil penelitian pada tabel 4.11 didapatkan informasi hasil rata-rata tekanan darah sistolik sebelum pemberian susu kedelai adalah $149,26 \mathrm{mmHg}$ dengan standar deviasi $10,350 \mathrm{mmHg}$, nilai minimum $140 \mathrm{mmHg}$ dan nilai maximum $180 \mathrm{mmHg}$. Pada pengukuran tekanan darah sesudah pemberian susu kedelai didapat rata-rata tekanan darah sistolik adalah 
Vol 10 No 1 Januari 2021 | Page 54-63

139,26 $\mathrm{mmHg}$ dengan standar deviasi $11,743 \mathrm{mmHg}$, nilai minimum $120 \mathrm{mmHg}$ dan nilai maximum $160 \mathrm{mmHg}$.

i. Rata-rata Tekanan Darah Diastolik Responden Sebelum dan Sesudah Pemberian Susu Kedelai

Tabel 4.12 Perbedaan Rata-rata Tekanan Darah Diastolik Responden Sebelum dan Sesudah Pemberian susu kedelai Pada Penderita Hipertensi di Desa Pringkumpul Pringsewu Selatan

\begin{tabular}{lccccc}
\hline \multicolumn{1}{c}{ Tekanan Darah } & Jumlah & Rata-rata & $\begin{array}{c}\text { Std. } \\
\text { Deviasi }\end{array}$ & Min & Max \\
\hline $\begin{array}{l}\text { Diastolik sebelum } \\
\text { Pemberian Susu Kedelai }\end{array}$ & 27 & 100,74 & 9,168 & 80 & 110 \\
& & & & & \\
Diastolik sesudah & & & & & \\
Pemberian Susu Kedelai & 27 & 90,74 & 9,168 & 80 & 110 \\
\hline
\end{tabular}

Berdasarkan hasil penelitian pada tabel 4.12 didapatkan hasil rata-rata tekanan darah diastolik sebelum pemberian susu kedelai adalah 100,74 mmHg dengan standar deviasi 9,168 $\mathrm{mmHg}$, nilai minimum $80 \mathrm{mmHg}$ dan nilai maximum $110 \mathrm{mmHg}$. Pada pengukuran tekanan darah diastolik sesudah pemberian susu kedelai didapat rata-rata tekanan darah diastolik $90,74 \mathrm{mmHg}$ dengan standar deviasi $9,168 \mathrm{mmHg}$, nilai minimum $80 \mathrm{mmHg}$ dan nilai maximum $110 \mathrm{mmHg}$. Terlihat perbedaan mean pada pengukuran tekanan darah sebelum dan sesudah pemberian susu kedelai sebesar $10,00 \mathrm{mmHg}$.

\section{Hasil Analisa Bivariat}

Analisis bivariat digunakan untuk menganalisis pengaruh pemberian susu kedelai terhadap penurunan tekanan darah pada penderita hipertensi dengan membandingkan tekanan darah sebelum dan sesudah Pemberian Susu Kedelai.

Perubahan Tekanan Darah Sebelum dan Sesudah Pemberian Susu Kedelai Pada Penderita Hipertensi di Desa Pringkumpul Pringsewu Selatan

Tabel 4.13 Perubahan Tekanan Darah Sistolik Sebelum dan Sesudah Pemberian susu kedelai Pada Penderita Hipertensi di Desa Pringkumpul Pringsewu Selatan

\begin{tabular}{ccccccc}
\hline Tekanan Darah & Jumlah & Rata-rata & Std. Deviasi & Min & Max & $\begin{array}{c}\text { Sig } \\
\text { (2-tailed) }\end{array}$ \\
\hline $\begin{array}{c}\text { Sistolik sebelum } \\
\text { Pemberian Susu } \\
\text { Kedelai }\end{array}$ & 27 & 149,26 & 10,350 & 140 & 180 & \\
& & & & & & 0,000 \\
$\begin{array}{c}\text { Sistolik sesudah } \\
\text { Pemberian Susu } \\
\text { Kedelai }\end{array}$ & 27 & 139,26 & 11,743 & 120 & 160 & \\
& & & & & & \\
\end{tabular}


Berdasarkan tabel 4.13 didapatkan hasil nilai rata-rata tekanan darah sistolik mengalami penurunan 10,00 mmHg. Dari hasil uji paried sample T-test didapatkan nilai $\rho$ value tekanan darah sistole yaitu 0,000 .

Tabel 4.14 Perubahan Tekanan Darah Diastolik Sebelum dan Sesudah Pemberian susu kedelai Pada Penderita Hipertensi di Desa Pringkumpul Pringsewu Selatan

\begin{tabular}{|c|c|c|c|c|c|c|}
\hline Tekanan Darah & Jumlah & $\begin{array}{c}\text { Rata- } \\
\text { rata }\end{array}$ & $\begin{array}{c}\text { Std. } \\
\text { Deviasi }\end{array}$ & Min & $\begin{array}{c}\text { Ma } \\
\mathbf{x}\end{array}$ & $\begin{array}{c}\text { Sig } \\
(2- \\
\text { tailed })\end{array}$ \\
\hline $\begin{array}{l}\text { Diastolik sebelum } \\
\text { Pemberian Susu } \\
\text { Kedelai }\end{array}$ & 27 & 100,74 & 9,168 & 80 & 110 & 0,000 \\
\hline $\begin{array}{l}\text { Diastolik sesudah } \\
\text { Pemberian Susu } \\
\text { Kedelai }\end{array}$ & 27 & 90,74 & 9,168 & 80 & 110 & \\
\hline
\end{tabular}

Berdasarkan tabel 4.14 didapatkan informasi bahwa nilai rata-rata tekanan darah diastolik mengalami penurunan 10,00 mmHg. Dari hasil uji paried sample T-test didapatkan nilai $\rho$ value tekanan darah sistole yaitu 0,000 .

\section{PEMBAHASAN}

Penelitian ini merupakan penelitian tentang pengaruh pemberian susu kedelai terhadap penurunan tekanan darah pada penderita hipertensi di Desa Pringkumpul Pringsewu Selatan. Pada pembahasan ini penulis akan membandingkan hasil tekanan darah pada penderita hipertensi sebelum dan sesudah Pemberian Susu Kedelai.

\section{Kelebihan dan Keterbatasan Penelitian}

Penelitian ini merupakan penelitian Quasi Eksperiment. Pada penelitian ini menggunakan jenis pendekatan One Group Pretest-posttest. Kelebihan dari penelitian ini dibandingkan dari penelitian sebelumnya yaitu intensitas penelitian yang diulang selama 12 (dua belas) hari dalam kurun waktu 2 bulan sehingga kekuatan dari penelitian ini lebih dari penelitian sebelumnya dengan pendekatan yang sama. Disamping terdapat kelebihan, penelitian ini juga masih memiliki keterbatasan. Penelitian ini tidak meggunakan kontrol grup yang memungkinkan terjadinya bias penelitian. Bias kemungkinan terjadi pada penelitian ini antara lain bias seleksi dimana dalam rentan waktu yang ditentukan penulis tidak mengikuti perkembangan responden dirumah, apakah mengkonsumsi obat-obatan penurun tekanan darah atau sejenisnya, serta pola hidup responden.

\section{Pengaruh tekanan darah sebelum dan sesudah Pemberian Susu Kedelai}

Hasil penelitian menunjukkan bahwa nilai rata-rata tekanan darah sistole setelah dilakukan mengalami penurunan $10,00 \mathrm{mmHg}$ dan nilai rata-rata tekanan darah diastole setelah dilakukan pemberian susu kedelai mengalami penurunan 10,00 $\mathrm{mmHg}$. Berdasarkan uji paried sample T-test 
didapatkan nilai $\rho$ value tekanan darah sistole yaitu 0,000 dan tekanan darah diastole yaitu 0,000. Nilai $\rho$ value sistole dan diastole kurang dari nilai $\alpha(0,05)$. Sehingga Ho ditolak, yang berarti ada pengaruh pemberian susu kedelai terhadap penurunan tekanan darah pada pasien dengan hipertensi

Hasil penelitian ini sejalan dengan penelitian Sinaga, (2012) yang membuktikan bahwa susu kedelai mempunyai pengaruh terhadap kadar glukosa darah puasa pada wanita prediabet dengan hasil terjadi penurunan bermakna $(p=0,001)$ sebesar $26.31 \pm 11.38 \mathrm{mg} / \mathrm{dL}$. Senada dengan Pambudi,(2014) dalam buku yang berjudul "Budidaya dan Khasiat Kedelai Edamame" yang menjelaskan bahwa protein kedelai dan isoflavon dapat melindungi tubuh dari kerusakaan radikal, meningkatkan sistem kekebalan, menurunkan resiko pengerasan arteri, penyakit jantung dan tekanan darah tinggi. Kedelai mengandung antioksidan yang dapat memperbaiki tekanan darah dan meningkatkan kesehatan pembuluh darah. Manfaat Susu kedelai diantaranya yaitu baik untuk penderita hipertensi karena mengandung isoflavon yang melancarkan metabolisme, melancarkan pencernaan, meningkatkan sistem imunitas, memperkuat struktur matriks, menstabilkan tekanan darah, menurunkan kadar kolesterol darah, menstabilkan kadar gula darah. Susu kacang memiliki komposisi yang mirip dengan susu: $3,5 \%$ protein, $2 \%$ lemak, serta 2,9\% karbohidrat.

Dari hasil penelitian ini juga didapatkan bahwa terdapat nilai tekanan darah sistolik yang mengalami kenaikan ada pula responden yang tidak mengalami perubahan (tetap). Hal ini bisa saja terjadi mengingat tekanan darah seseorang dipengaruhi oleh banyak faktor antara lain usia, jenis kelamin, kebiasaan merokok, obesitas, stress, konsumsi natrium berlebih. Sehingga ketiak responden diberikan susu kedelai tetapi faktor risisko masih melekat maka pemberian susu kedelai menjadi tidak begitu bermakna. Faktor diatas bisa menjadi salah satu penyebab tekanan darah responden yang mengalami kenaikan setelah dilakukan pemberian susu kedelai, responden mengkonsumsi susu kedelai namun tidak mengontrol penggunaan garam dalam makanannya, begitu juga dengan kelebihan berat badan responden, faktor stres juga mungkin dialami responden saat terapi namun tidak teridentifikasi karena peneliti tidak melakukan pengumpulan data untuk faktor-faktor diatas.

Hasil dari beberapa penelitian menunjukkan bahwa pemberian susu kedelai berpengaruh terhadap penurunan tekanan darah sehingga penulis mengharapkan bagi masyarakat untuk bisa lebih memahami tentang susu kedelai serta manfaatnya oleh karena susu kedelai merupakan salah satu tanaman pengobatan herbal yang alami tanpa bahan kimia sehingga lebih baik untuk metode pengobatan khususnya hipertensi. Serta bagi dunia kesehatan dapat menggunakan pemberian susu kedelai sebagai salah satu terapi komplementer dalam mengatasi hipertensi. Tidak hanya di Desa akan tetapi penulis mengharapkan agar pemberian susu kedelai dapat dikolaborasikan dengan pengobatan medis dibalai pengobatan lainya sehingga perawatan seperti halnya tekanan darah yang tidak kunjung turun dapat segera dilakukan Pemberian Susu Kedelai.

\section{SIMPULAN}

Berdasarkan uji paried sample T-test didapatkan nilai $\rho$ value tekanan darah sistole yaitu 0,000 dan tekanan darah diastole yaitu 0,000 . Nilai $\rho$ value sistole dan diastole kurang dari nilai $\alpha(0,05)$. Sehingga Ho ditolak, yang berarti ada pengaruh pemberian susu kedelai terhadap penurunan tekanan darah pada pasien dengan hipertensi 
Vol 10 No 1 Januari 2021 | Page 54-63

\section{SARAN}

Bagi masyarakat penelitian ini agar menjadi bahan acuan salah satu alternatif pengobatan untuk menurunkan tekanan darah pada penderita hipertensi khususnya untuk masyarakat di Desa Pringkumpul Pringsewu Selatan.

\section{DAFTAR PUSTAKA}

Alimul, H.A., (2011). Metode Penelitian Keperawatan dan Teknik Analisa Data. Jakarta : Salemba Medika

Budimarwanti. *2010). Komposisi dan Nutrisi pada Susu Kedelai. Yogyakarta : FMIPA UNY.

Depkes RI, (2013). Laporan Hasil Riset Kesehatan Dasar (Riskesdas). Depkes RI. Jakarta

Dinkes Kabupaten Pringsewu, 2014. Profil Kesehatan Kabupaten Pringsewu.

Dicky. (2013). Pengaruh Terapi Bekam Basah Terhadap Tekanan Darah. Diakses pada tanggal 27 Februari (2014)

Kurniasari, K. dan N. Fitri. (2014). Optimasi Penambahan Alginate Sebagai Emulsifier pada Susu Kedelai dengan Variasi Kecepatan, Waktu, dan Suhu Pengadukan. Skripsi. Universitas Diponegoro. http://eprints.undip.ac.id/16676 14 Pebruari 2014.

Muhammadun. (2010). Hipertensi, Jakarta : PT Gramedia

Murniasiha. (2014). Effect of saybaen protein on blood pressure: a randomized, controlled trial. Stikes Muhammadiyah Gombong.

Notoadmodjo,S. (2010).Metodologi Penelitian Kesehatan. Jakarta : Rineka Cipta.

Pambudi, S. (2014). Budidayadan Khasiat Kedelai Edamame. Yogyakarta. Pustaka Baru Press.

Sinaga, Evi dan Wirawanni, Yekti. (2012). Pengaruh Pemberian Susu Kedelai Terhadap Kadar Glukosa Darah Puasa pada Wanita Prediabet. Universitas Diponegoro

Sulistyo, A.T. (2014). Pengaruh Terapi Bekam Terhadap Penurunan Tekanan Darah Pada Pasien hipertensi di Klinik Sehat Kosasih Sukabumi Bandar Lampung Tahun 2014. Pringsewu : STIKes Muhammadiyah Pringsewu

Syamsudin. 2011. Buku Ajar Farmakoterapi Kardiovaskuler dan Renal. Jakarta. Salemba Medika

Udjianti, W.J. (2017). Keperawatan Kardiovaskuler. Jakarta: Salemba Medik

Wahyuningtyas. (2010). Pengaruh Pemberian Ekstraks Mengkudu Terhadap Penurunan Tekanan Darah Pada Penderita Hipertensi di Desa Ujungwatu Kecamatan Donorojo Kabupaten Jepara. Skripsi. STIKes Telogorejo Semarang. 